\title{
Description of a new species of Distenia (Coleoptera, Disteniidae, Disteniini) from Southeastern China, with records and diagnoses of similar species
}

\author{
Wen-Xuan Bi ${ }^{1,2, \dagger}$, Mei-Ying Lin ${ }^{1, \dagger}$ \\ I Key Laboratory of Zoological Systematics and Evolution, Institute of Zoology, Chinese Academy of Sciences, \\ Beichen West Road, Chaoyang Dist., Beijing, 100101, China 2 Room 401, No. 2, Lane 155, Lianhua South \\ Road, Shanghai, 201100 China \\ † urn:lsid:zoobank.org:author:B53A211A-4D87-4478-8629-20DC127DA964 \\ $\ddagger$ urn:lsid:zoobank.org:author:4725CAC1-80E0-442D-BAFD-D5723AE41B6B \\ Corresponding author: Mei-Ying Lin (linmeiying@ioz.ac.cn) \\ Academic editor: S. Lingafelter | Received 17 January 2013 | Accepted 30 January 2013 | Published 4 March 2013 \\ urn:lsid:zoobank.org:pub:3BF23495-F804-4F63-B1C9-FD569153F1B5 \\ Citation: Bi WX, Lin MY (2013) Description of a new species of Distenia (Coleoptera, Disteniidae, Disteniini) from \\ Southeastern China, with records and diagnoses of similar species. ZooKeys 275: 77-89. doi: 10.3897/zookeys.275.4700
}

\begin{abstract}
A new species, Distenia orientalis sp. $\mathbf{n}$. is described from Southeastern China. It was misidentified as D. gracilis (Blessig, 1872) but can be separated from the latter by the color of antennae and legs, structure differences on scape, maxillary palp, pronotum, tibiae, punctures on elytra, etc. Three related species are carefully diagnosed and treated.
\end{abstract}

\section{Keywords}

Distenia orientalis, new species, taxonomy, Oriental region, Disteniidae

Copyright Wen-Xuan Bi, Mei-Ying Lin. This is an open access article distributed under the terms of the Creative Commons Attribution License 3.0 (CC-BY), which permits unrestricted use, distribution, and reproduction in any medium, provided the original author and source are credited. 


\section{Introduction}

During research on the fauna of Tianmushan, the first author, Wenxuan Bi, experienced difficulties with identification of Distenia gracilis (sensu Gressitt 1951; Chen et al. 1959). The fresh material he collected from Tianmushan of Zhejiang Province seems very different from that from Northeastern China and continental Russia. After studying further material from different localities, we conclude that there are three species among the specimens hitherto identified as D. gracilis: D. gracilis (Blessig, 1872), D. japonica Bates, 1873 and D. orientalis sp. n.

Material studied is deposited in the following institutions and private collections:

CBWX Collection of Wenxuan Bi, Shanghai, China

CCCC Collection of Chang-chin Chen, Tianjin, China

CJM Collection of Ming Jin, Shanghai, China

CYZZ Collection of Zhizhou Yu, Shanghai, China

CZDY Collection of Deyao Zhou, Shanghai, China

IZAS Institute of Zoology, Chinese Academy of Sciences, Beijing, China

MD Collection of Mikhail L. Danilevsky, Moscow, Russia

NHML The Natural History Museum, London, UK

SNUC The Insect Collection of Shanghai Normal University, Shanghai, China

ZMAS Museum of Zoology, Academy of Sciences, Saint-Petersburg, Russia

ZMMU Zoological Museum of Moscow University, Moscow, Russia

\section{Results}

\section{Distenia gracilis (Blessig, 1872)}

http://species-id.net/wiki/Distenia_gracilis

Figs $1-15,37-38$

Apheles gracilis Blessig, 1872: 168, pl. VIII, fig. 1; Ganglbauer 1887: 131.

Distenia gracilis: Kraatz 1879: 91; Plavilstshikov 1936: 105, 492, fig. 70; Gressitt 1951: 45 [part]; Chen et al. 1959: 32, Pl. III, fig. 16 [part]; Lee 1987: 9, pl. I, fig. 1; Švácha and Danilevsky 1987: 38 [part]; Cherepanov 1990: 68; Hua 2002: 189 [part]; Hua et al. 2009: 448 [part]; Lin et al. 2010: 120 [part]; Danilevsky 2012: 902.

Host plant. Alnus sp. (BETULACEAE), Chosenia sp. (SALICACEAE) (Danilevsky 2012). Remarks. This species was first recorded from Northeastern China (Manchuria) by Plavilstshikov (1936). Gressitt (1951) cited this information and added Zhejiang (Tianmushan) as a new locality, which was the first misidentification. Then, Chen et al. (1959) followed Gressitt (1951) and made a drawing based on specimens from Tianmushan, which misled subsequent Chinese longicornists to misidentify D. orientalis sp. n. as D. gracilis. Therefore, the record from Zhejiang and Jiangxi 


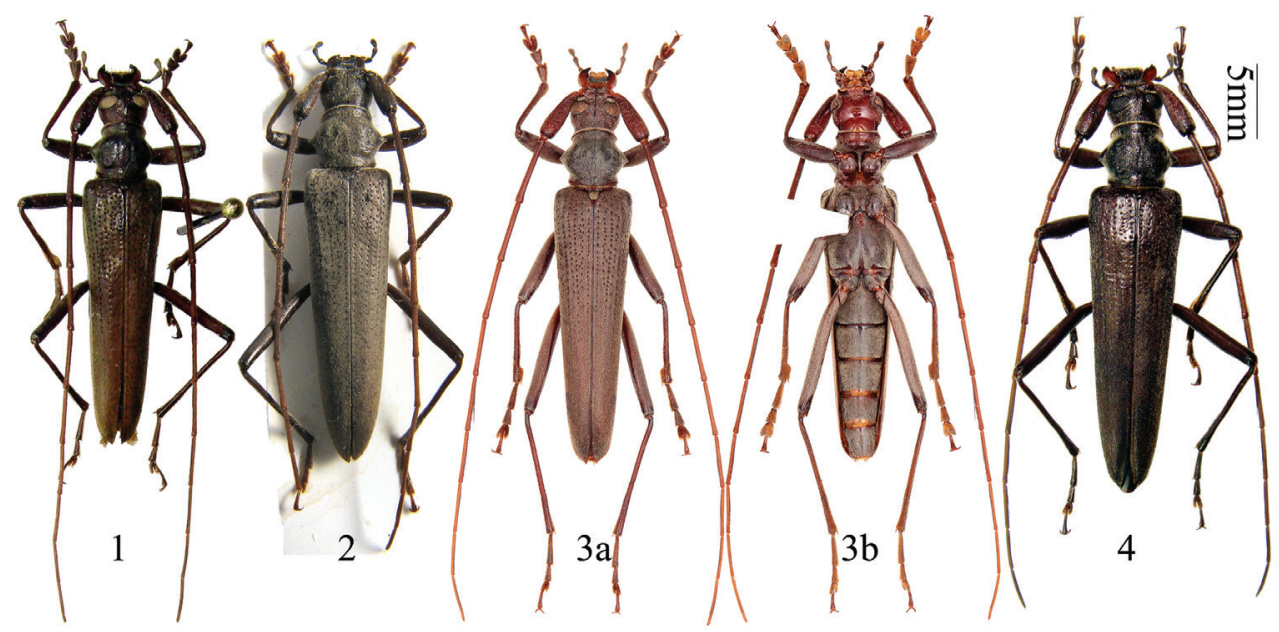

Figures I-4. Distenia gracilis (Blessig, 1872). I male, from Far East Russia 2 female, from Far East Russia 3 male, from Liaoning, China a dorsal view b ventral view 4 female, from Liaoning, China. Scale 5 mm.

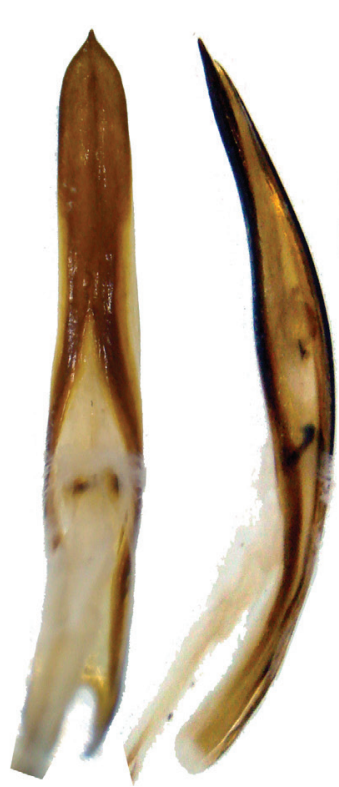

$5 \mathrm{a}$

$5 b$

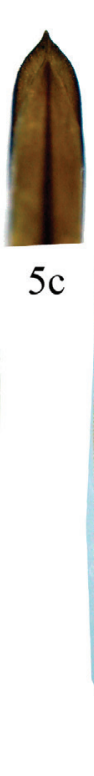

6

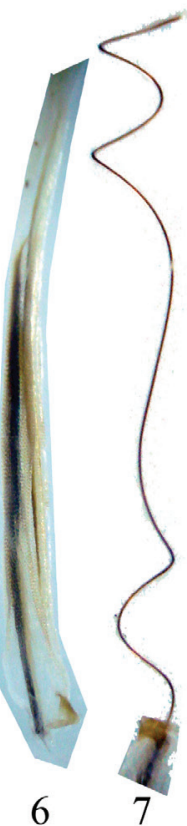

7

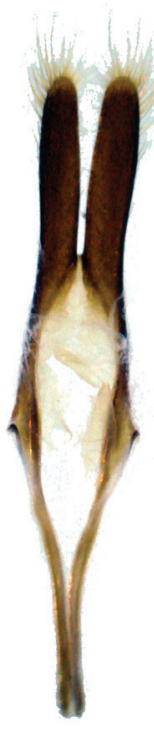

$8 \mathrm{a}$

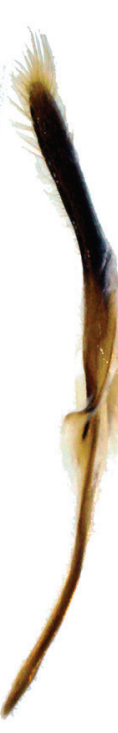

$8 b$

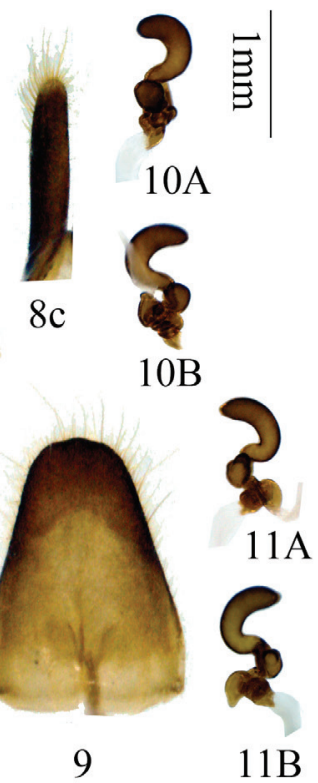

$11 \mathrm{~B}$

Figures 5-I I. Genitalia of Distenia gracilis (Blessig, 1872). 5-9 male, from Far East Russia 5 median lobe $\mathbf{6}$ rods of endophallus $\mathbf{7}$ hair-like thin rod of ejaculatory duct $\mathbf{8}$ tegmen $\mathbf{a}$ ventral view $\mathbf{b}$ lateral view. c dorsal view 9 tergite VIII in dorsal view I0-I I female, spermathecal capsule, both from Liaoning, China. A-B from different sides. Scale $1 \mathrm{~mm}$.

is incorrect, as it was based on misidentification of $D$. orientalis sp. n. The records from Hubei and Anhui are doubtful and may also be based on misidentification of $D$. orientalis sp. $\mathrm{n}$. (or another species) but we did not have specimens available from these 


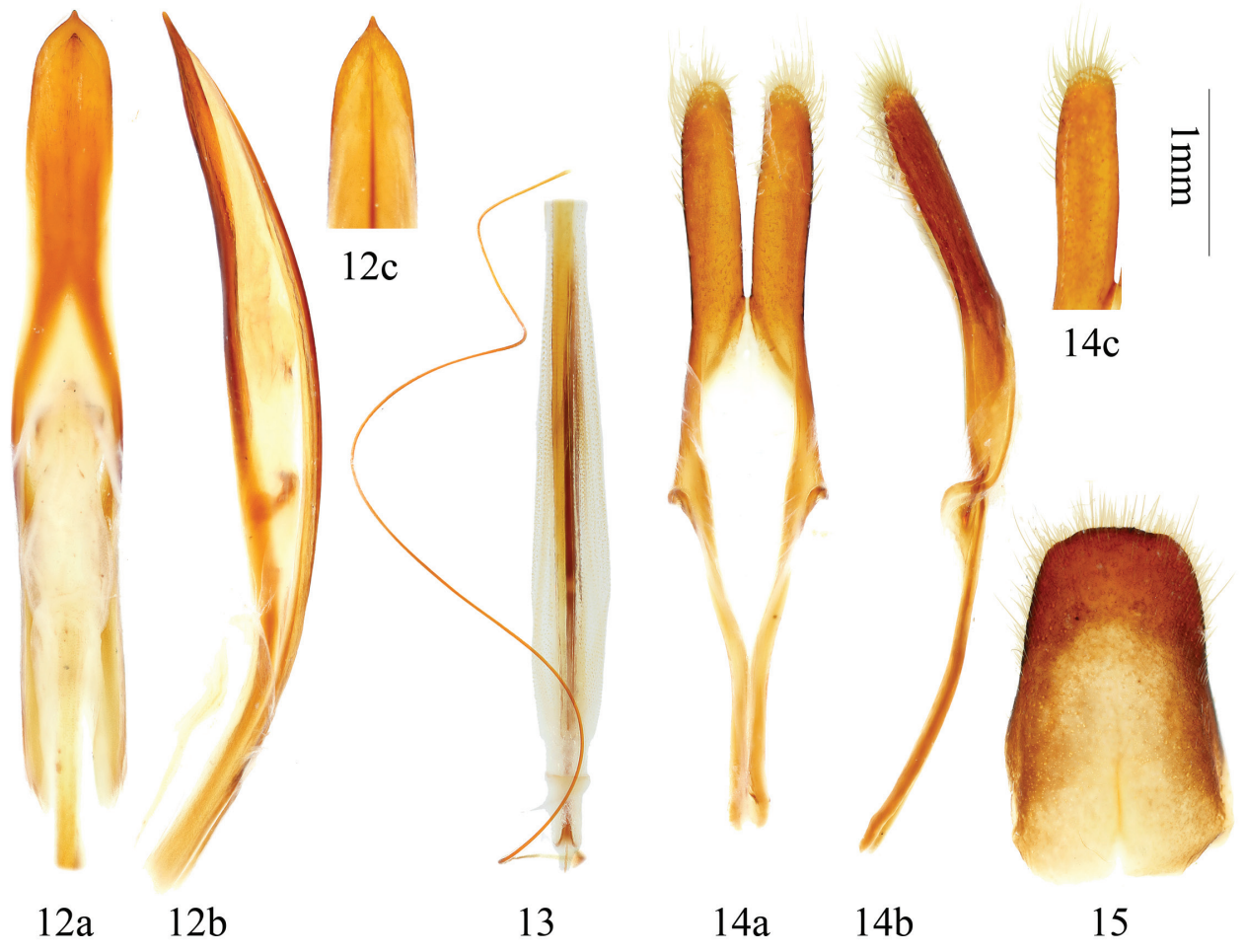

Figures I2-15. Genitalia of Distenia gracilis (Blessig, 1872), male, from Liaoning, China $\mathbf{2}$ median lobe $\mathbf{I} \mathbf{3}$ rods of endophallus, including hair-like thin rod of ejaculatory duct $\mathbf{I} \mathbf{4}$ tegmen a ventral view b lateral view c dorsal view $\mathbf{I} \mathbf{5}$ tergite VIII in dorsal view. Scale $1 \mathrm{~mm}$.

two provinces. Chou (2004) didn't include D. gracilis in his book on Taiwanese fauna. Records of $D$. gracilis from Japan were based on misidentification of $D$. japonica.

We did not have specimens from Korea for study. We consider the record by Ganglbauer (1887) and Lee (1987) correct based on the pictures by Lee (1987).

The holotype of Apheles gracilis Blessig, 1872 is a male from Russia, Sibérie (Amurland), collected by P. Wulffius. It was supposed to be deposited in ZMAS. We could not reach the curators in ZMAS. According to personal communication by Mikhail Danilevsky, he could not find the type in the collection of ZMAS.

Distribution. North China (Heilongjiang, Jilin, Liaoning), Korea (including South Korea and North Korea), Russia (Far East).

Specimens examined. China, Liaoning: 2 females, Benxi, Guanmenshan, 2011. VIII.21, coll. Xinlei Huang (IZAS); 1 male 1 female, Dandong, Saima, Wendong, 2006.IX.1, 3, coll. Haicheng Shan (IZAS, ex CCCC); 2 males, Dandong, Saima, Pushihe, 2008.VII.30, coll. Haicheng Shan (CBWX).

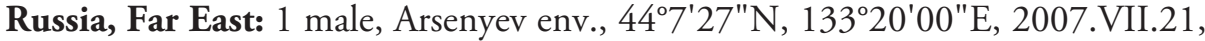
coll. S. Ivanov (MD); 1 male, Primorie Reg., Chernigovka distr., Merkushevka Env., $44^{\circ} 22^{\prime} 2.52^{\prime \prime} \mathrm{N}, 132^{\circ} 48^{\prime} 0.42^{\prime \prime E}, 2011$.VII.28-30, coll. S. Ivanov (MD). 


\section{Distenia japonica Bates, 1873}

http://species-id.net/wiki/Distenia_japonica

Figs 16-24, 39-40

Distenia japonica Bates, 1873: 155.

Distenia gracilis: Kraatz 1879: 91; Švácha and Danilevsky 1987: 38 [part]; Lin et al. 2010: 120 [part].

Distenia gracilis gracilis: Ohbayashi and Niisato 2007: 335, pl. 1, figs 1 (male) \& 2 (female) [Fauna].

Distenia japonica: Danilevsky 2012: 902.

Host plant. It is polyphagous with the following host plants recorded under D. gracilis (confused with D. japonica): Acer sp. (ACERACEAE), Abies sachalinensis Masters (PINACEAE), Alnus sp. (BETULACEAE), Betula sp. (BETULACEAE), Chosenia sp. (SALICACEAE), Picea sp. (PINACEAE), Pinus sp. (PINACEAE), Quercus sp. (FAGACEAE), Salix sp. (SALICACEAE), Ulmus sp. (ULMACEAE).

Diagnosis. According to Danilevsky (2012), Distenia gracilis Blessig, 1872 (mainland and Sakhalin) and D. japonica Bates, 1873 (islands) are different vicariant species, very easily distinguished by narrow scapus in $D$. japonica. Further differences are shown in Table 1.

Remarks. This species was first described by Bates (1873) based on syntypes from Japan, Honshu (Hyogo Prefecture), Maiyasan, collected by George Lewis. Kraatz (1879) synonymized it with $D$. gracilis, which was widely followed by subsequent authors until Danilevsky (2012) resurrected it.

Švácha and Danilevsky (1987) pointed out the habit differences between the mailand population and island population, and suspected "it is possible that we are facing two separate taxa". "However, reliable larval morphological differences have

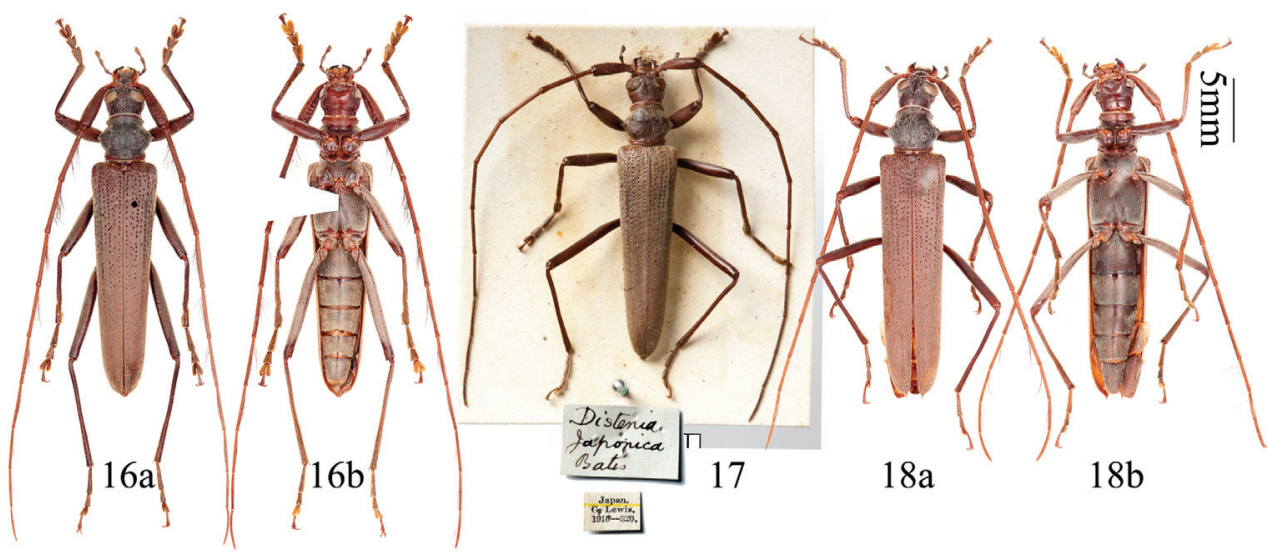

Figures 16-18. Distenia japonica Bates, 1873. 16 male, from Iwate, Japan 17 syntype, male, from Hyogo, Japan $\mathbf{8}$ female, from Iwate, Japan a dorsal view b ventral view. Scale $5 \mathrm{~mm}$. 
Table I. Differences of D. gracilis, D. japonica and D. orientalis sp. n.

\begin{tabular}{|c|c|c|c|}
\hline Character Species & D. gracilis & D. japonica & D. orientalis sp. n. \\
\hline $\begin{array}{l}\text { Antennal segment } \\
\text { extending beyond tip } \\
\text { of elytra }\end{array}$ & in male $8^{\text {th }}$, in female $9^{\text {th }}$ & in male $8^{\text {th }}$, in female $9^{\text {th }}$ & in male $7^{\text {th }}$, in female $8^{\text {th }}$ \\
\hline $\begin{array}{c}\text { Color of antennae and } \\
\text { legs }\end{array}$ & uniformly black-brown & Uniformly brown & $\begin{array}{l}\text { Mostly black-brown, with } \\
\text { several orange-red rings }\end{array}$ \\
\hline Scape in male & $\begin{array}{l}\text { With basal grooves, } \\
\text { punctures coarser }\end{array}$ & $\begin{array}{l}\text { With basal grooves, } \\
\text { punctures finer }\end{array}$ & $\begin{array}{l}\text { Without basal grooves, } \\
\text { with rugose punctures }\end{array}$ \\
\hline $\begin{array}{l}\text { Scape length / } \\
\text { maximum width }\end{array}$ & $\begin{array}{c}\text { ca.3.0 in male, ca. } 2.8 \text { in } \\
\text { female }\end{array}$ & $\begin{array}{c}\text { ca.3.5 in male, ca. } 3.0 \text { in } \\
\text { female }\end{array}$ & $\begin{array}{c}\text { ca.3.1 in male, ca. } 3.4 \text { in } \\
\text { female }\end{array}$ \\
\hline $\begin{array}{l}\text { Last segment of } \\
\text { maxillary palp }\end{array}$ & $\begin{array}{c}\text { Stouter, length / } \\
\text { maximum width }<2.5 \text { in } \\
\text { male, }<2.6 \text { in female (Figs } \\
37 \mathrm{a}, 38 \mathrm{a})\end{array}$ & \begin{tabular}{|c} 
Stoutest, length / maximum \\
width $<2.1$ in male, $<2.4$ \\
in female (Figs 39a, 40a)
\end{tabular} & $\begin{array}{c}\text { Slender, length / } \\
\text { maximum width }>2.5 \\
\text { in male, }>3.0 \text { in female } \\
\text { (Figs 41a, 42a) }\end{array}$ \\
\hline Pronotum & $\begin{array}{l}\text { Without transverse rugae, } \\
\text { swelling indistinct (Figs } \\
37 c, 38 c \text { ) }\end{array}$ & $\begin{array}{l}\text { Without transverse rugae, } \\
\text { swelling more distinct (Figs } \\
\text { 39c, 40c) }\end{array}$ & $\begin{array}{l}\text { With some transverse } \\
\text { rugae (Figs 41c, 42c) }\end{array}$ \\
\hline Mosotibiae of male & $\begin{array}{l}\text { Apical protruding lobe } \\
\text { very distinct (Fig. } 37 f \text { f) }\end{array}$ & $\begin{array}{l}\text { Apical protruding lobe } \\
\text { distinct (Fig. 39f) }\end{array}$ & $\begin{array}{l}\text { Without apical } \\
\text { protruding lobe (Fig. } \\
\text { 41f) }\end{array}$ \\
\hline Punctures on elytra & $\begin{array}{l}\text { With distinct longitudinal } \\
\text { rows, the row near suture } \\
\text { not very dense (Figs } 37 \mathrm{~d} \text {, } \\
38 \mathrm{~d} \text { ) }\end{array}$ & $\begin{array}{l}\text { With distinct longitudinal } \\
\text { rows, the row near suture } \\
\text { very dense (Figs 39d, 40d) }\end{array}$ & $\begin{array}{l}\text { Longitudinal rows } \\
\text { indistinct, the row near } \\
\text { suture very sparse (Figs } \\
41 \mathrm{~d}, 42 \mathrm{~d} \text { ) }\end{array}$ \\
\hline Sternite VII (ventrite V) & Figs $37 \mathrm{e}, 38 \mathrm{e}$ & Figs $39 \mathrm{e}, 40 \mathrm{e}$ & Figs $41 \mathrm{e}, 42 \mathrm{e}$ \\
\hline Median lobe & Figs 5, 12 & Figs 19 & Figs 29 \\
\hline Spermathecal capsule & Figs $10-11$ & Figs 24 & Figs 34-36 \\
\hline
\end{tabular}

not been found." (Švácha and Danilevsky 1987). According to Danilevsky (2012), D. gracilis (mainland and Sakhalin) develops underground on healthy roots of living Chosenia (personal observation in Kedrovaya Pad) and on Alnus, but D. japonica lives under the old dead bark of many different trees (personal observation on Kunashir), often together with Eutetrapha. Therefore, the host plants recorded under D. gracilis could actually be host plants of D. japonica.

Distribution. Japan, Russia (Far East, Islands).

Specimens examined. Japan: 1 male, syntype, Japan (NHML, ex collection G. Lewis, examined through pictures); 1 male, Japan, Iwate Prefecture, Niisato-mura, Genbeidaira, 1982.VII.31, coll. N. Ohbayashi (CBWX); 1 female, Japon, Iwate Prefecture, Niisato-mura, Genbeidaira, 1982.VII.31, coll. N. Ohbayashi (CBWX); 1 male 1 female, Kyoto, Kibone, 1932.VII.1, coll. S. Yie (IZAS); 1 female, Tokushima, Mt. Tsurugi, 1971.VII.11, coll. H. Toshima (IZAS); 1 female, Tottori Pref., Mt. Hokki-Daisan, 1958.VII.22, coll. H. Toshima (IZAS). 


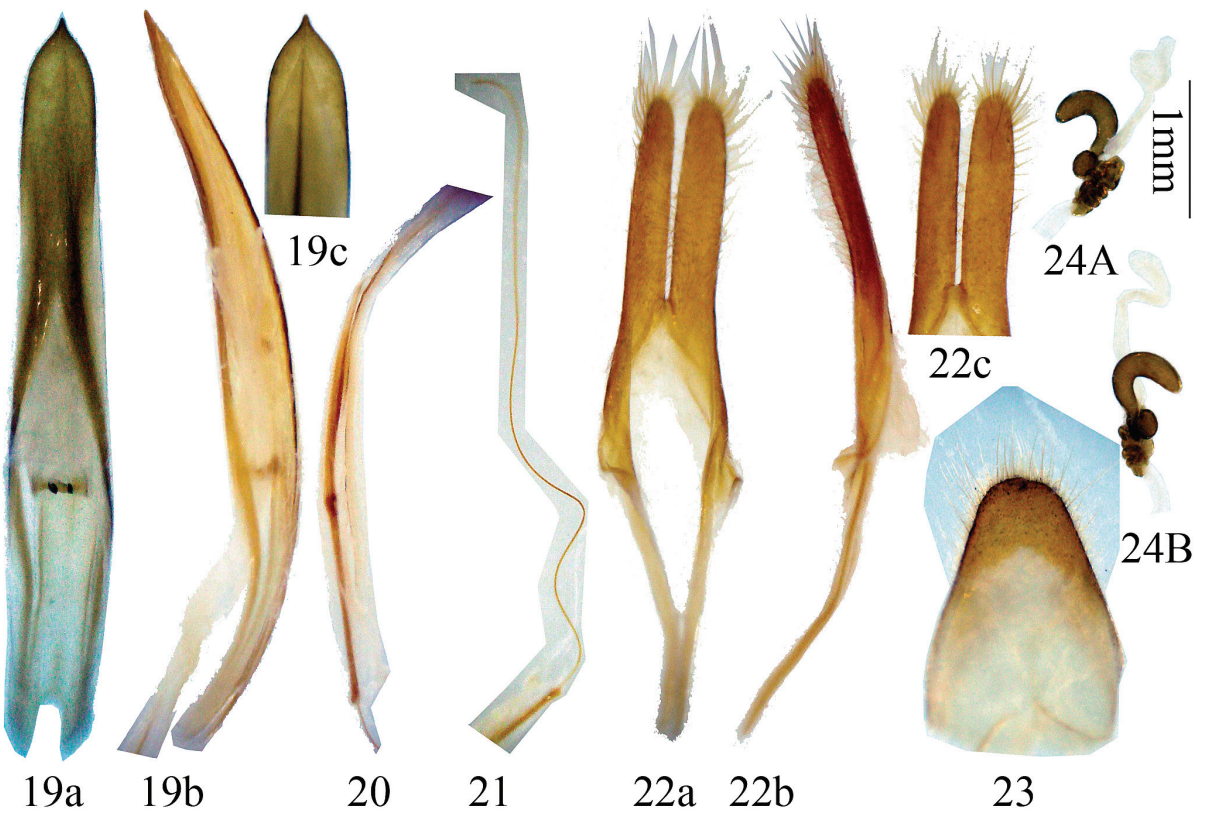

Figures 19-24. Genitalia of Distenia japonica Bates, 1873. 19-23 male, from Kyoto, Japan 19 median lobe $\mathbf{2 0}$ rods of endophallus $\mathbf{2} \mathbf{I}$ hair-like thin rod of ejaculatory duct $\mathbf{2 2}$ tegmen. $\mathbf{a}$ ventral view $\mathbf{b}$ lateral view $\mathbf{C}$ dorsal view $\mathbf{2 3}$ tergite VIII in dorsal view $\mathbf{2 4}$ female, spermathecal capsule, from Kyoto, Japan. A-B from different sides. Scale $1 \mathrm{~mm}$.

\section{Distenia japonica yakushimana Yokoyama, 1966}

http://species-id.net/wiki/Distenia_japonica_yakushimana

Distenia gracilis yakushimana Yokoyama, 1966: 54, pl. 6, fig. 1.

Distenia gracilis yakushimana: Ohbayashi and Niisato 2007: 336, pl. 1, fig. 3 (male)

[Fauna].

Distenia japonica yakushimana: Danilevsky 2012: 902.

Diagnosis. According to Yokoyama (1966): "This subspecies differs from the typical species (D. japonica), in having the following points: body smaller and more blackish, sparsely covered with shorter brownish yellow pubescence, which is sparser on head and prothorax. Clypeus longer, vertex less punctured. Prothorax weakly irregularly wrinkled, lateral tubercles less developed, not acute at apex. Terminal joint of maxillary palpus rounded at apex (instead of truncate)."

Remarks. This subspecies was described based on the female holotype from Japan, Ryukyu island, Mt. Miyanouradake (alt. 1200 m), collected by Hajime Yokoyama on August 3, 1962. It is deposited in Osaka Museum of Natural History. We did not examine the holotype or other specimens but followed Ohbayashi and Niisato (2007) and Danilevsky (2012) in treating this form as a subspecies.

Distribution. Japan (Yaku-shima). 


\section{Distenia orientalis sp. $\mathbf{n}$.}

urn:lsid:zoobank.org:act:14814F4C-97D8-4C2C-9125-7AA5DEDACFA6 http://species-id.net/wiki/Distenia_orientalis

Figs 25-36, 41-42

Distenia gracilis: Gressitt 1951: 45 [part]; Chen et al. 1959: 32, Pl. III, fig. 16; Hua 2002: 189 [part]; Hua et al. 2009: 448 [part]; Lin et al. 2010: 120 [part].

Description. Male: body length $18.7-25.5 \mathrm{~mm}$, width at humeri $4.0-6.0 \mathrm{~mm}$. Female: body length $22.0-26.6 \mathrm{~mm}$, width at humeri $5.0-6.5 \mathrm{~mm}$. Body uniformly black-brown, with rusty tinge (especially in male), except bases of tibiae (about $1 / 3$ to $1 / 2$ ), tips of antennal segments IV-XI (increasing from IV to XI), and extreme tips of last segments of maxillary and labial palps which are reddish-brown, and ventral side of tarsi and base of mandible being brown.

Body elongate, slender. Head with dense rugose punctures, with mouthparts turned forward and somewhat downward. Last segment of maxillary palp expanded and obliquely truncate apically. Frons between eyes with narrow interrupted longitudinal suture. Antennae long; scape very thick in male and more slender in female, without a groove on basal half, in male with coarse rugose punctures (Fig. 41a), in female not rugose but with finer punctures (Fig. 42a); scape not reaching midlength of pronotum in either sex; pedicel very small; subsequent segments slender; in male $7^{\text {th }}$, in female $8^{\text {th }}$ segment extends beyond tip of elytra; antennal segments with recumbent long hairs beneath. The relative length of antennal segments, male: 10.6:1:12.9:13.2:13.1:12.5:11.9:11.1:9.7:8.7:8.8 (variable in narrow range); female: 9.9:1:10.2:10.3:10.3:10.1:9.5:8.5:7.4:6.5:6.3 (variable in narrow range).

Pronotum broadest in middle, with acute conical lateral spines, near posterior and anterior margins with slight transverse constriction, with rugae on disc, and with dense minute punctures and dense gray pubescence. Scutellum not longer than width at base, apically rounded, with yellowish pubescence.

Elytra narrow, taper uniformly toward apex, length 3.0-3.4 times the total width at humeri, and anterior half with deep punctures forming several indistinct longitudinal rows. Abdominal ventrite $\mathrm{V}$ in female (Figs 26b, 34d) elongate, gently rounded posteriorly; in male (figs 28b, 33d) distinctly emarginate, with minute tender closely recumbent hairs. Legs long and slender, mesotibiae (of both male and female) without apical protruding lobe.

Male terminalia (Figs 29-33): Tegmen (Fig. 32) approximately $5.0 \mathrm{~mm}$ in length; lateral lobes slender, length about 5 times the width, ventral side and apex with short setae; median lobe plus median struts (Fig. 29) slightly curved, longer than tegmen; the median struts less than $1 / 8$ of the whole median lobe in length; apex of ventral plate bluntly pointed; internal sac bearing a basal armature (Fig. 29b) and two median rods of endophallus (Figs 30,31), of which the strongly sclerotized one (coming from the gonopore) connected to a very long (much longer than the median rods) hair-like rod (inside ejaculatory duct, Fig. 30). Tergite VIII (Fig. 33) longer than broad, narrowed apically from middle, with rounded apex, apical half bearing short dorsal setae. 


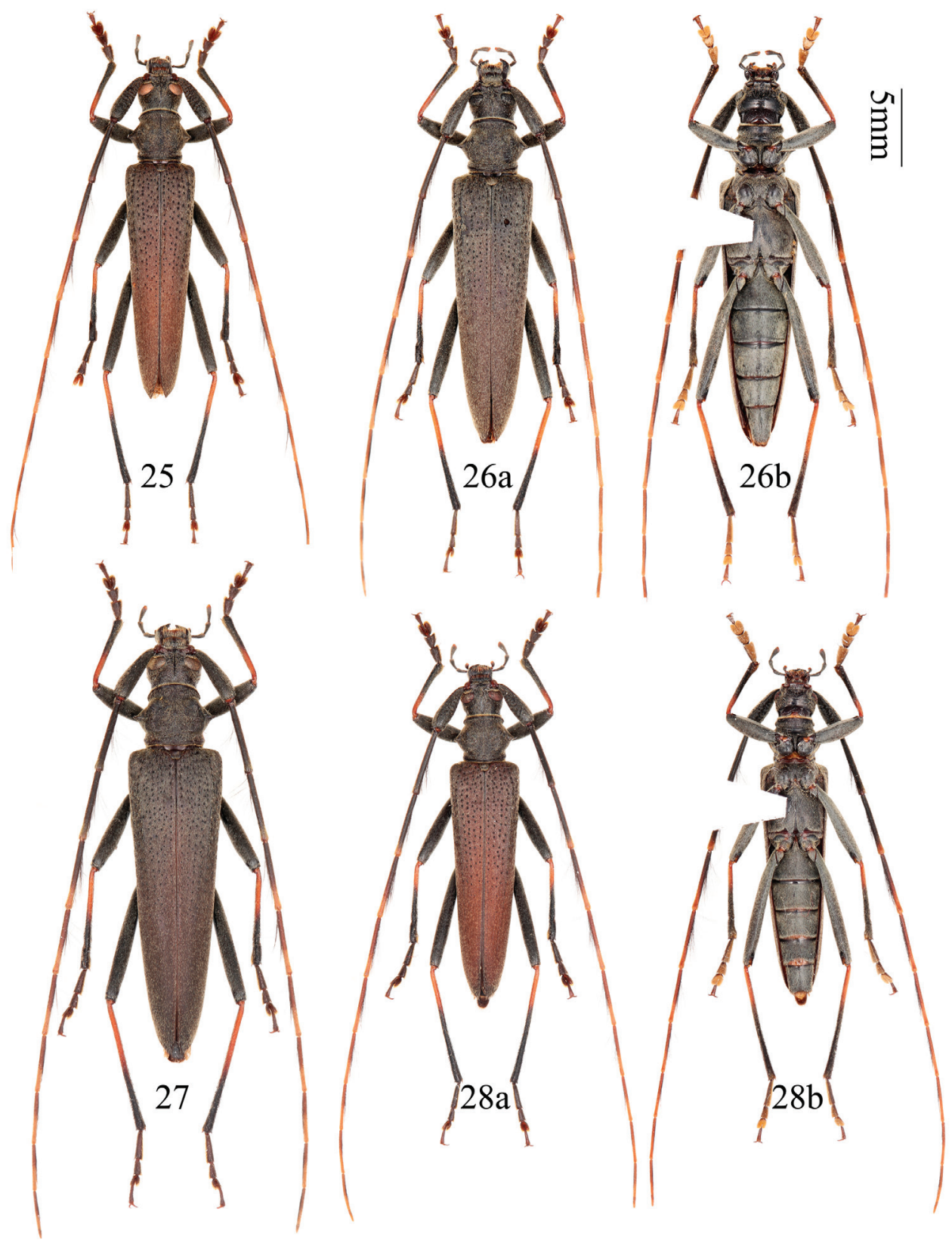

Figures 25-28. Distenia orientalis sp. n. 25 holotype, male, from Xitianmushan, Zhejiang, China $\mathbf{2 6}$ paratype, female, from Tianmushan, Zhejiang, China $\mathbf{2 7}$ paratype, female, from Fengyangshan, Zhejiang, China 28 paratype, male, from Wuyishan, Fujian, China a dorsal view b ventral view. Scale $5 \mathrm{~mm}$.

Female terminalia (Figs 34-36): Paraproct moderate in size, its baculi thick and long, straight and not bifurcate at base; valvifer indistinct; coxite with rough surface, each baculum very thick at base and narrowed towards apex; coxite lobes sclerotized 


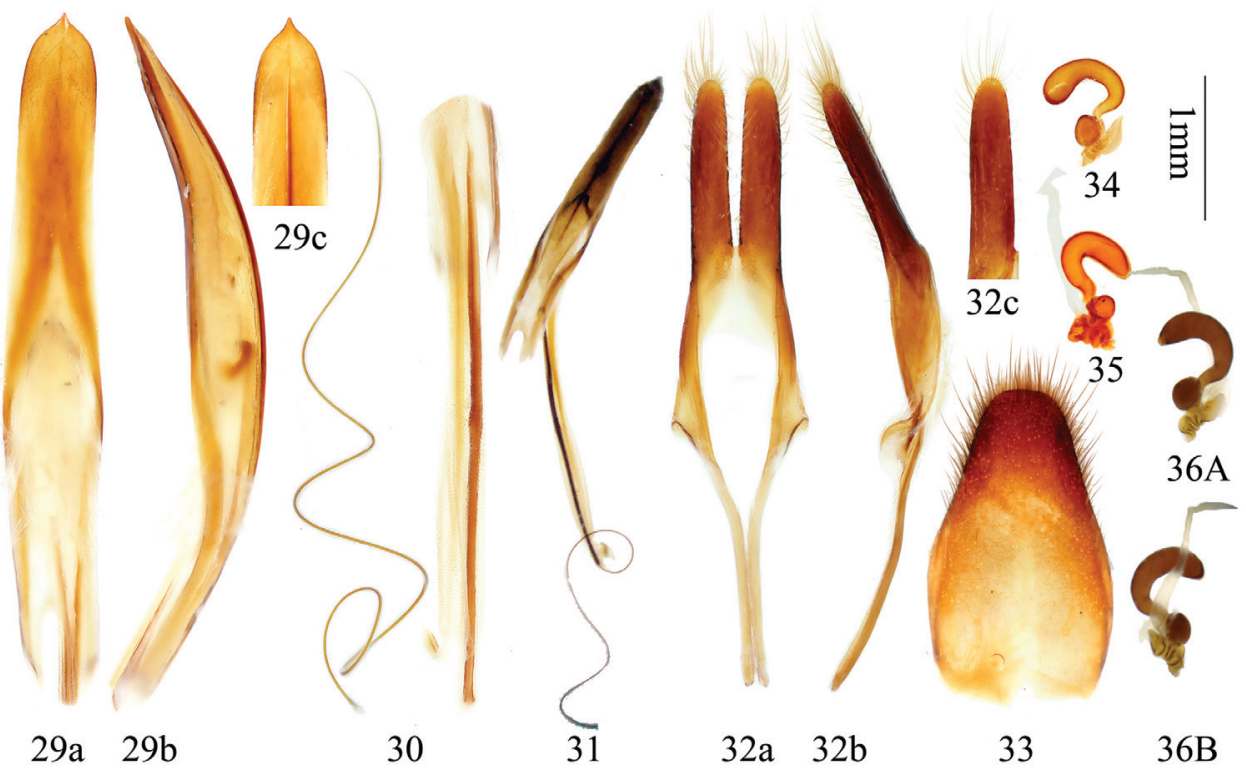

Figures 29-36. Genitalia of Distenia orientalis sp. n. 29-33 male, from Xitianmushan, Zhejiang, China $\mathbf{2 9}$ median lobe $\mathbf{3 0}$ rods of endophallus and hair-like thin rod of ejaculatory duct $\mathbf{3} \mathbf{I}$ whole median lobe, showing the position of rods of endophallus, not to scale $\mathbf{3 2}$ tegmen $\mathbf{a}$ ventral view $\mathbf{b}$ lateral view $\mathbf{c}$ dorsal view 33 tergite VIII in dorsal view 34-36 female, spermathecal capsule $\mathbf{3 5}$ from Fengyangshan, Zhejiang, China $34 \& \mathbf{3 6}$ from Tianmushan, Zhejiang, China. A \& B from different sides. Scale $1 \mathrm{~mm}$.

at each inner part, with tactile hairs; stylus articulated to the tip of each coxite lobe (slightly laterally), sclerotized except for apex and bearing tactile hairs; dorsal baculi sinuate and longer than paraproct baculi; proctiger baculi long and almost straight. Spermathecal capsule (Figs 34-36) large, heavily sclerotized and of very intricate structure, its apical part narrow, strongly bent at middle and basally with a protrusion (in shape of a question mark "?"), basal part irregularly twisted and with rather broad protrusion to which attaches the spermathecal gland at the middle part. Tignum much shorter than half of abdomen. In one measured specimen, tignum was $4.4 \mathrm{~mm}$ for an adult with $12.0 \mathrm{~mm}$ abdomen length in ventral view.

Diagnosis. The differences of the three species are shown in Table 1.

Etymology. The name of the new species refers to its distribution in southeast China, instead of northeast China (which is the distribution of D. gracilis).

Remarks. This species has been misidentified as D. gracilis since Gressitt (1951).

It is the $29^{\text {th }}$ recorded species for the Chinese Disteniidae fauna (Lin et al. 2010; Lin and Murzin 2012).

One female from Mt. Wutaishan of Shanxi Province shows a strange dot on the distributional map. We believe that the distribution region will be extended after further survey.

Distribution. China: Zhejiang Prov., Fujian Prov., Guangdong Prov., Jiangxi Prov., Shanxi Prov. 


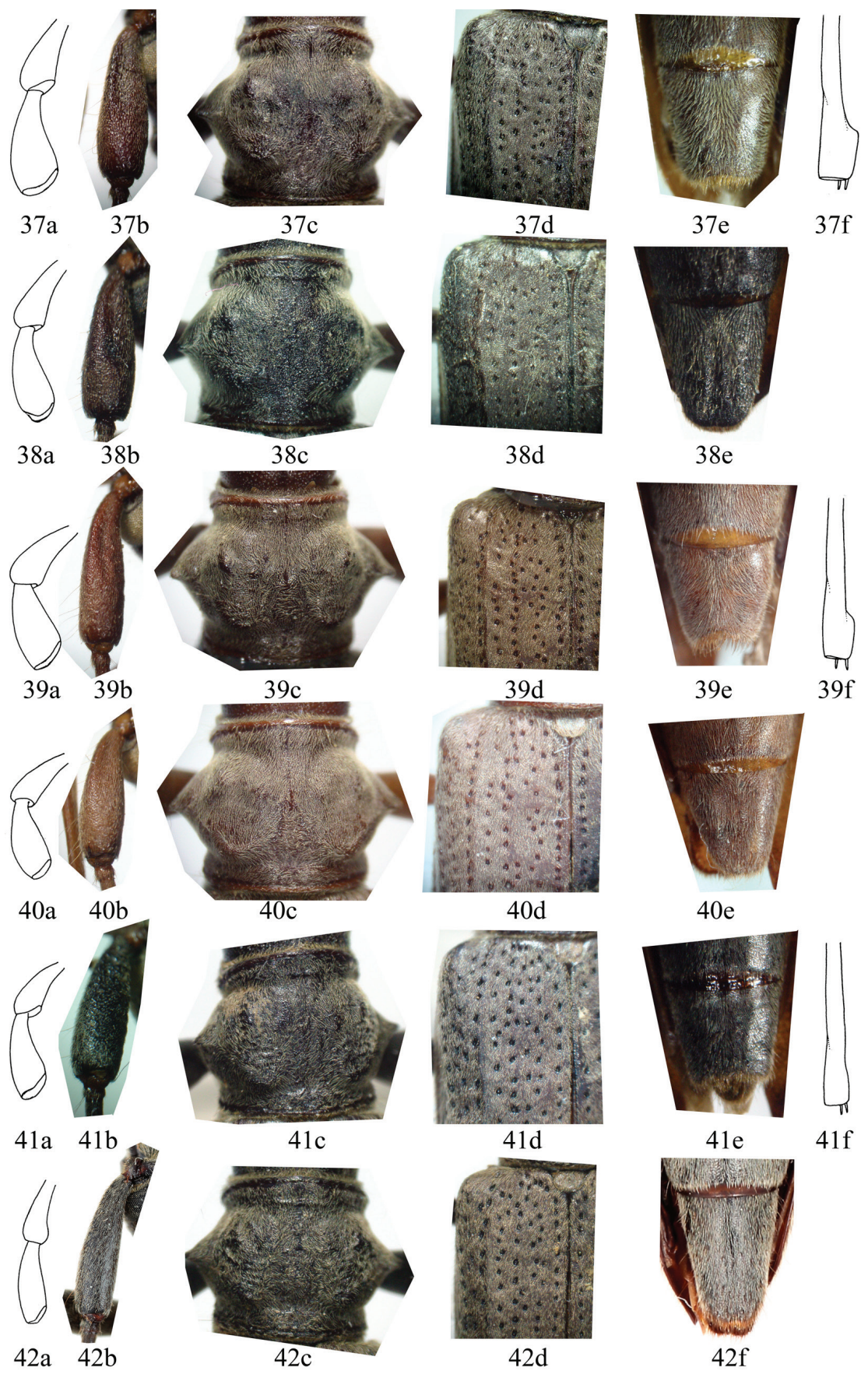

Figures 37-42. Six important characters of Distenia spp. not to scale. 37-38 D. gracilis. 37 male from Far East, Russia 38 female from Liaoning, China 39-40 D. japonica 39 male from Kyoto, Japan $\mathbf{4 0}$ female from Kyoto, Japan 4I-42 D. orientalis sp. n. 41 male from Tianmushan, China $\mathbf{4 2}$ female from Tianmushan, China a last segment of maxillary palp, showing the tip and the ration of length to width $\mathbf{b}$ scape c pronotum $\mathbf{d}$ basal part of elytron e ventrite $\mathrm{V} \mathbf{f}$ mesotibia of male, showing the apical protruding lobe. 
Specimens examined. Holotype, male, Zhejiang, Xitianmushan, alt. 1200 m, 2008. VII.2, coll. Hao Huang (SNUC, ex CBWX). Paratypes: China, Zhejiang: 1 male, Xitianmushan, alt. 1300 m, 2009.IV.19 (larva), 2009.V.14 (adult), coll. Wenxuan Bi (CBWX); 1 male, Xitianmushan, alt. 1100 m, 2008.III.1 (larva), 2008.V.27 (adult), coll. Wenxuan Bi (CBWX); 1 female, Tianmushan nature reserve, alt. 1100 m, 2008.VII.30, coll. Yongxiang Wu (CJM); 1 female, China, Chekiang, Tien-mu-shan, 1937.VI.30, coll. E. Surnson (ZMMU); 1 female, Xitianmushan, alt. 1000m, 2012.VII.11, coll. Deyao Zhou (CZDY); 1 female, Tienmushan, 1937.VIII.3 (IZAS, IOZ(E)1859289); 2 males, same data (IZAS, IOZ(E)1859290-91); 2 males, same data but 1937.VIII.4 (IZAS, IOZ(E)1859292-93); 1 male, same data but 1937.VII.21 (IZAS, IOZ(E)1859288); 1 female, Longquan, Fengyangshan, Lu'ao village, alt. 1100 m, 2008.VII.31, coll. Wenxuan Bi (CBWX); Qingyuan county, Baishanzu nature reserve, alt. 1000 m, 2009. VII.25-VIII.5, coll. Zhizhou Yu (CYZZ). China, Fujian: 1 male, Chong'an, Sangang, 1979.VIII.14 (IZAS, IOZ(E)1859287); 1 male, Fujian, Wuyishan nature reserve, 2009. VII.10-15. coll. Ming Jin (CJM). China, Jiangxi: 1 female, Wuyishan nature reserve, Yejiachang station, alt. 900 m, 2004.VIII.2 (CCCC). China, Guangdong: 1 female, Ruyuan county, Nanling nature reserve, 2008-2009, coll. Lei Gao (CCCC).

Additional specimen examined. China, Shanxi: 1 female, Wutaishan, alt. 2000 m, 1996.VII.17, coll. Wenzhu Li (IZAS, IOZ(E)1859062).

\section{Acknowledgements}

We wish to express our sincere thanks to Yulong Lin (Taiwan, China) for the meaningful discussion at the beginning of this research, to Steven W. Lingafelter (National Museum of Natural History, Smithsonian Institution, Washington, USA), Mikhail Danilevsky (IEER) and Michiaki Hasegawa (Toyohashi Museum of Natural History, Aichi, Japan) for improving this manuscript. Our special thanks are due to Alexey Gusakov (ZMMU), Changchin Chen (CCCC), Deyao Zhou (CZDY) and Zhizhou Yu (CYZZ) for giving us the permission to use the related collections and for providing material and information. We thank Paul Hurst and Sharon L. Shute (NHML) for taking the syntype pictures of Distenia japonica Bates for us, and thank Wenzhu Li (IZAS) for making the pictures of maxillary palpi and mesotibiae. Special thanks are due to Jennifer Hammock and Steven W. Lingafelter (Smithsonian Institution, National Museum of Natural History, Washington, USA) for their kindly improving the English. This research was supported by a grant (No. O529YX5105) from the Key Laboratory of the Zoological Systematics and Evolution of the Chinese Academy of Sciences, and by NSFC program J1210002 and 31000967.

\section{References}

Bates HW (1873) On the Longicorn Coleoptera of Japan. The Annals and Magazine of Natural History, London (4) 12(68): 148-156. 
Chen S, Xie YZ, Deng GF (1959) Economic insect fauna of China Vol. I Coleoptera: Cerambycidae. Science Press, Beijing, 120 pp.

Cherepanov AI (1990) Cerambycidae of Northern Asia, volume 1, Prioninae, Disteniinae, Lepturinae, Aseminae. Pauls Press, New Delhi, 642 pp.

Danilevsky ML (2012) Additions and corrections to the new Catalogue of Palaearctic Cerambycidae (Coleoptera) edited by I. Löbl and A. Smetana, 2010. Part. VI. Humanity Space. International Almanac 1(4): 900-943.

Gressitt JL (1951) Longicornia Volume II: Longicorn Beetles of China. Paul Lechevalier, Paris, 667 pp.

Hua LZ (2002) List of Chinese Insects Vol. II. Zhongshan (Sun Yat-sen) University Press, Guangzhou, 612 pp.

Hua LZ, Nara H, Samuelson GA, Lingafelter SW (2009) Iconography of Chinese Longicorn Beetles (1406 Species) in Color. Series Publications of Museum of Biology Sun Yat-sen University. Sun Yat-sen University Press, Guangzhou, 474 pp.

Kraatz G. (1879) Ueber die Bockkäfer Ost-Sibiriens, namentlich die von Christoph am Amur gesammelten. Deutsche entomologische Zeitschrift 23(1): 77-117.

Lee SM (1987) The Longicorn Beetles of Korean Peninsula. National Science Museum, Seoul, Korea, 287 pp.

Lin MY, Liu Y, Bi WX (2010) Newly recorded species of Disteniidae (Coleoptera) from China, with a catalogue of Chinese Disteniidae. Entomotaxonomia 32(2): 116-128.

Lin MY, Murzin SV (2012) A study on the apterous genus Clytomelegena Pic, 1928 (Coleoptera, Disteniidae). ZooKeys 216: 13-21. doi: 10.3897/zookeys.216.3769

Ohbayashi N, Niisato T (2007) Longicorn Beetles of Japan. Tokai University Press, Kanagawa, 818 pp.

Plavilstshikov NN (1936) Faune de l'URSS. Insectes Coléoptères. Cerambycidae (P. 1). Moscou-Leningrad. Fauna SSSR 21(1): 1-611.

Švácha P, Danilevsky ML (1987) Cerambycoid larvae of Europe and Soviet Union (Coleoptera, Cerambycoidea). Part I. Acta Universitatis Carolinae (Biologica) 30: 1-176.

Yokoyama H (1966) The Cerambycidae from Ryukyu and Satsunan Islands, I. (Coleoptera). The Entomological Review of Japan 18(2): 54-59. 